\title{
IMPLEMENTASI PENDIDIKAN PADA MASA COVID-19 DALAM PERSPEKTIF SOSIOLOGI
}

\author{
Mutiyati, Yuniarti \\ Universitas Islam Negeri Raden Fatah Palembang \\ mutyatichan@gmail.com \&yuniarti280@gmail.com
}

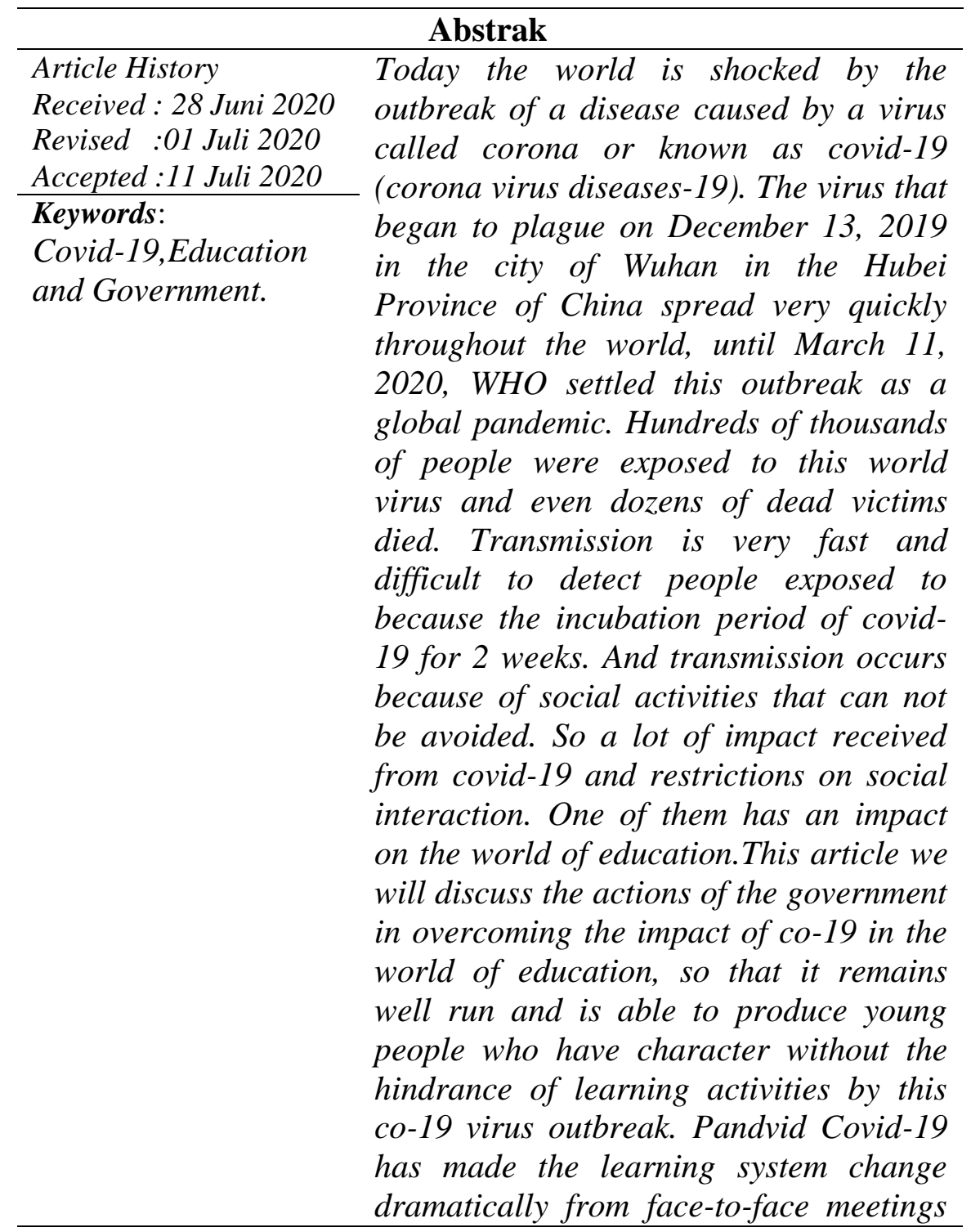


to online learners. This study uses a survey method using a questionnaire conducted online. The Tarbiyah and Teacher Training faculties support learning policies at home by implementing online learning.

\section{Pendahuluan}

Tanggal 2 Maret 2020 Presiden Joko Widodo mengumumkan kasus pertama Covid-19 di Indonesia (Pengumuman Mendadak Jokowi yang Kejutkan Pasien Positif Corona... n.d.), dan menghimbau masyarakat untuk mengurangai aktivitas diluar rumah demi menekan penyebaran virus corona Covid-19 di Indonesia. Jokowi meminta masyarakat indonesia untuk melakukan spcial distancing untuk mencegah penyebaran Virus Corona. Upaya untuk mencegah, menahan, atau memperlambat penularan corona melalui social distancing. Sejak diberlakukan sosial dictancing memberi dampak bagi pendidikan melalui Surat Edaran Kemdikbud No 4 Tahun 2020 mengenai Pelaksanaan Pendidikan Dalam Masa Darurat Corona virus Disease (Covid-19) (Kementerian Pendidikan dan Kebudayaan » Republik Indonesia n.d.) mulai diberlakukannya pembelajaran daring/jarak jauh.

Kondisi dunia yang terkena dampak Covid-19, kegiatan pembelajaran dialihkan pada kelas online atau virtual. (Anderson 2008, 5) menyatakan bahwa secara berangsur-angsur, banyak organisasi mengadopsi Online Learning sebagai metode penyampaian utama untuk melatih para pegawai. Meskipun penggunaan sistem belajar online merupakan suatu yang relative mahal, namun dapat ditarik suatu manfaat yang sangat besar dari strategi tersebut baik bagi peserta didik maupun bagi pendidik. Mahalnya pembelajaran online juga masih bisa terjangkau menggantikan biaya transportasi ketika harus datang ke kelas. (Punaji Setyosari 2007, 7-8) menyatakan bahwa pembelajaran melalui jaringan memiliki potensipotensi, antara lain: kebermaknaan belajar, kemudahan mengakses, dan peningkatan hasil belajar. Dalam konteks belajar secara online, mahasiswa dapat berhubungan secara cepat dan langsung dengan teks, gambar, suara, data, dan video dua arah, dengan bimbingan pengajar. Tutorial tatap muka diganti dengan perantara teknologi yang disebut tuweb diharapkan hasil belajar mahasiswa menjadi bagus di tengah 
maraknya virus covid-19.

(Amri Tanduklangi 2019, 2), misalnya, telah melakukan kajian terhadap 59 hasil penelitian yang berkenaan pembelajaran berbantuan komputer dan hasil belajar. Kajian penelitian yang memfokuskan pada teknologi ini ternyata lebih baik daripada kajian yang membahas dampak teknologi terhadap lingkungan belajar secara keseluruhan dan hasil belajar pebelajar. Untuk itu dengan tuweb/bantuan teknologi yang mengikuti proses tutorial, akan menghasilkan prestasi mahasiswa yang meningkat, karena tidak hanya penguasaan materi melainkan juga menguasai teknologinya. Dari rumah saja, tetap menjalankan physical distancing, tetapi ilmu pengetahuan tetap terus upgrade. Program pemerintah memutus mata rantai penyebaran covid-19 bisa terwujud, dan cita-cita tujuan negara dalam bidang pendidikan akan tercapai. Pembaharuan modus belajar melalui daring bukan tidak mungkin akan menjadi pilihan walaupun keadaan negara telah aman.

\section{Metode Penelitian}

\section{Pendekatan dan Jenis Penelitian}

Penelitian Metode yang digunakan dalam penelitian ini adalah metode kualitatif (Moleong 2018, 2) yang bertujuan menjelaskan mengenai solusi pembelajaran dalam menghadapi covid-19.

\section{Teknik Pengambilan Data}

Teknik pengambilan data dengan memakai pola pendekatan studi kepustakaan. yaitu studi yang objek penelitiannya berupa karyakarya kepustakaan, baik berupa jurnal ilmiah, buku ataupun artikel (Creswell 2013, 36). Studi kepustakaan merupakan suatu kegiatan yang tidak dapat dipisahkan dari penelaahan terhadap suatu objek kajian.

\section{Waktu dan Tempat Penelitian}

Dikerjakan dirumah waktu pengerjaan penelitian dimulai pada selasa, 18 mei 2020 sampai dengan kamis, 20 mei 2020.

\section{Fokus Penelitian}

Dalam penelitian yang menggunakan penelitian kualitatif berarti isi penelitian menyeluruh sehingga fokus penelitian untuk menjadi batasan dalam suatu penelitian. Penelitian berfokus pada 
pembelajaran daring dan tindakan pemerintah dalam menghadapi pandemi covid-19.

\section{Sumber Data Penelitian}

Teori teori yang mendasari masalah dan bidang yang diteliti dapat ditemukan dengan melakukan studi kepustakaan. Selain itu seorang peneliti dapat memperoleh informasi tentang penelitianpenelitian sejenis ataupun penelitian yang sudah dilakukan sebelumnya. Kepustakaan tersebut akan diinventarisir sesuai dengan data yang dibutuhkan. Sehingga peneliti dapat melakukan analisis secara kritis terkait dengan implementasi pendidikan pada masa covid-19.

\section{Pembahasan \\ Konsep Pelaksanaan}

Teori pelaksanaan menurut Edward dan Emerson, Grindle, serta Mize dalam (Rama 2014, 10) menjelaskan bahwa terdapat empat variabel kritis dalam implementasi kebijakan publik atau program diantaranya komunikasi atau kejelasan informasi, ketersediaan sumberdaya dalam jumlah dan mutu tertentu, sikap dan komitmen dari pelaksana program atau kebijakan birokrat atau standar operasi yang mengatur tata kerja dan tata laksana.

Menurut (Kurniasih and Sani 2014, 16) "pelaksanaan yaitu sebuah tindakan atau juga pelaksanaan dari suatu rencana yang telah disusun secara terperinci dan matang, penerapan biasanya dilakukan setelah perencanaan.” Sedangkan menurut (Wildavsky 2017, 199) mengemukakan "pelaksanaan sebagai evaluasi serta perluasan aktivitas yang saling menyesuaikan." Maka dapat disimpulkan pelaksanaan adalah suatu tindakan atau pelaksanaan dari sebuah rencana yang sudah disusun secara matang dan terperinci, implementasi biasanya dilakukan setelah perencanaan sudah dianggap siap.

1. Covid 19

Memasuki tahun 2020 masyarakat global termasuk Indonesia, dihebohkan dengan sebaran virus bernama Corona (lebih dikenal dengan Covid-19). Kasus dan awal penyebaran Covid-19 ini ditengarai berasal dari Kota Wuhan, Cina, pada akhir tahun 2019 yang kemudian menyebar secara global ke seluruh negara di dunia (Kisah dari Wuhan, Awal Pandemi Virus Corona yang Tidak Akan 
Terlupakan... n.d.). Walaupun kemudian muncul counter opini melalui berita bahwa asal mula penyeberan Covid-19 berasal dari Amerika Serikat, Eropa bahkan ada yang mengatakan dari Indonesia, namun hal ini tidak terlalu penting. Yang jelas, realitas hari ini penyebaran Covid-19 sudah hampir ke seluruh negara di belahan bumi ini.

Virus lain sangat berbeda dengan Covid-19, sebarannya sulit terdeteksi dan menyebar hampir ke seluruh dunia. Sehingga Covid-19 berdampak sangat serius terhadap tatapola dan sendi kehidupan masyarakat global di semua negara, mulai dari sendi sosial, ekonomi, kesehatan, politik, budaya, hukum, dan keagamaan.

2. Pembelajaran Daring

Pembelajaran daring/jarak jauh untuk memberi pengalaman belajar yang bermakna, tanpa terbebani tuntutan menuntaskan seluruh capaian kurikulum untuk kenaikan kelas maupun kelulusan. Pembelajaran daring dapat difokuskan pada pendidikan kecakapan hidup, antara lain mengenai pandemi Covid-19. Aktivitas dan tugas pembelajaran dapat bervariasi antar siswa, sesuai minat dan kondisi masing-masing, termasuk mempertimbangkan kesenjangan akses/fasilitas belajar di rumah.

Pembelajaran daring tidak dapat dilakukan jika sekolah maupun orangtua tidak memiliki kapital memadai untuk mengakses perangkatnya. Pembelajaran ini tidak akan terjadi ketika guru dan siswa sama-sama tidak memiliki komputer, handphone, atau kuota dan jaringan internet yang memadai. Beruntung, belakangan pemerintah membolehkan anggaran Dana BOS untuk mendukung pelaksaan pembelajaran daring.

3. Tindakan Pemerintah

Kementerian dalam sebuah Pendidikan telah memberikan izin kepada sebuah sekolah menggunakan unruk dana bos guna membeli kuota pulsa (Kepala Sekolah, Sekarang Bisa Pakai Dana BOS untuk Pulsa dan Kuota Internet n.d.) adapun Kebijakan ini diharapkan dapat membantu proses belajar daring baik bagi guru maupun siswa. Selain daripada sekolah, selain daripada itu. Pemerintah juga memberikan izin kepada perangkat desa untuk menggunakan alokasi dana untuk membantu para pendidik dalam belajar daring atau belajar dalam jaringan serta perangkat desa 
juga diantisipasi untuk mendukung upaya tersebut dengan regulasi yang fleksibel.

Untuk mengatasi kepincangan, saat ini KEMENDIKBUD telah menyediakan pembelajaran melalui TVRI dan RRI mulai 13 April lalu (5 Fakta tentang Program Belajar dari Rumah di TVRIkumparan.com n.d.). melalui pendekatan ini diharapkan dapat menjangkau lebih banyak peserta didik. Acara ini juga harus bisa mengakomodasi kepentingan anak berkebutuhan khusus, seperti penggunaan bahasa isyarat. Pembelajaran jarak jauh memberikan kemudahan dan kesempatan dalam berbagai kondisi. Tidak pernah diprediksi sebelumnya keadaan dunia terkena covid-19. Untuk memotong mata rantai penyebaran, kita tetap dapat melakukan banyak hal positif di rumah.

4. Partisipasi dari Pihak-Pihak

Partisipasi guru dalam mendesain pembelajaran daring bagi siswa juga memegang peranan penting. Untuk memastikan pembelajaran menjadi menyenangkan, penuh makna, membangkitkan kreativitas, daya kritis, dan mampu membuat siswa mandiri tentu bukan perkara mudah. Apalagi guru tidak dapat secara langsung berhadap-hadapan dengan siswa. Kejelian guru dalam membuat desain dan metode yang mampu memikat siswa untuk terus bersemangat belajar menjadi hal yang patut diperhatikan. Jika hanya memberi beban tugas kepada siswa tentu membuat siswa menjadi jenuh. Partisipasi orangtua menjadi sangat penting untuk menyukseskan pembelajaran daring. Situasi dilematis kemudian terjadi ketika orangtua tidak dapat hadir mendampingi anak karena masih harus bekerja.

Mereka adalah orang-orang yang tidak memiliki kemewahan untuk bekerja dari rumah. Para petugas kesehatan, pekerja informal, buruh pabrik, peternak, nelayan, dan petani misalnya harus tetap bekerja. Sementara mereka tidak memiliki orang lain yang dapat membantu mendapingi anak. Para orang tua yang memiliki kesempatan bekerja dari rumah tetapi tetap memprioritaskan pekerjaan kantor juga tidak dapat membantu anak-anak belajar secara optimal. Khusus bagi anak-anak di usia dini ini tentu menjadi perkara.

Jika kedua orangtua bekerja dan mereka tidak memiliki asisten rumah tangga misalnya, mereka harus mampu membagi peran untuk mengasuh anak. Jika tidak dapat disikapi secara bijak, 
lagi-lagi isu kesehatan mental menjadi bagian yang perlu diantisipasi. Pembelajaran daring telah membuka berbagai problem pendidikan di negeri ini. Selain itu semakin menunjukkan bahwa pembangunan pendidikan di Indonesia membutuhkan dukungan dari berbagai pihak. Pendidikan sebagai suatu ekosistem utuh yang tidak lepas dari kebijakan politik, daya dukung teknologi, infrastruktur yang memadai, serta dukungan dari orangtua/ masyarakat. Tanpa itu semua, pendidikan tidak dapat optimal dalam mencerdaskan anak bangsa.

\section{Pembelajaran daring dalam covid-19}

Yang menjadi efek atau dampak yang terlihat daripada virus corona adalah ketertundaan berbagai agenda pendidikan yang dianggap sangat penting. Baik imbas iotu dirasakan obagi dunia pendidikan di Indonesia, baik dampak dalam sekolah ataupun untuk perguruan tinggi pada khususnya. Adapun tugas yang dianggap sangat penting diantaranya yaitu ujian sekolah anak, pecan perkenalan siswa dan siswi baru. Sedangkan kegiatan penting dalam perguruan tinggi yaitu pengabdian masyarakat karena dianggap dapat meminimalisir dan menghindari kerumunan atau membuat kerumunan. Dan sebagai warga yang taat dan patuh terhadap peraturan dalam upaya pencegahan penularan virus tersebut.

Terjadinya kesinjangan akses media pembelajaran, antara anak dari keluarga ekonomi yang mampu dan anak dari kalangan kurang mampu. Dan peneliti juga menemukan bahwa hanya sekitar $28 \%$ penjawab pertanyaan dalam penelitian yang menyatakan anak mereka belajar dengan menggunakan media dalam jaringan. Terkait peran orang tua yang menyatakan perbandingan antara kelompok ibu yang menyediakan waktu lebih banyak dibandingkan kaum ayah dalam mendampingi anak belajar dari rumah. kebanyakan orang tua yang paham informasi belajar dari rumah dari sisi penyebaran informasi kebijakan "Belajar dari Rumah", kurang lebih 95\% orang tua mengatakan sekolah anak mereka sudah menerapkan kebijakan tersebut. Walaupun kebijakan nasional resmi baru terbit 24 Maret 2020, 76\% orang tua mengatakan sekolah telah menerapkan kebijakan itu lebih awal. Penggunaan media belajar luring lebih diminati dibandingkan daring.

Perhitungan sekitar kurang lebih $28 \%$ yang menegaskan bahwa putra dan putri mereka belajar dengan menggunakan alat komunikasi 
dalam jaringan dan menggunakan media penghunbung belajar lainnya ataupun menggunakan aplikasi belajar online (Evaluasi dan Optimalisasi Pembelajaran Daring n.d.). Sebaliknya, pemakaiana melalui alat atau media pembelajaran luring dengan menggunakan buku dan lembar kerja siswa adalah metode yang paling sering (66\%) dipergunakan oleh pendidik. Sebagian lagi yaitu sekitar $6 \%$ orang tua mengatakan bahwa selama belajar dirumah. Anak-anak tidak mendapatkan materi belajar untuk dirumah. Ditinjau dari persentase semakin terpencil daerah tersebut, maka akan menjadi persentase kecil untuk anak didik mendapatkan jangkauan system daring atau dalam dalam sebuah jaringan internet. Di Jatim sekitar 40\% responden menyatakan bahwa anak mereka mendapatkan pembelajaran daring. Sedangkan di Mataram pembelajaran online kurang dari $10 \%$ dan di daerah kupang kurang dari 5\%. Selebihnya melalui offline buku dan lembar kerja siswa dapat dipastikan bagaimana daerah terpencil lainnya dalam pemakaian media daring lainnya.

Seperti yang diketahui, anak-anak diberikan sebuiah tugas yang mana anak-anak dituntut untuk menyelesaikan dengan menggunakan media daring. Semua anak yang menyelesaikan bisa dipersentasekan sekitar $87 \%$ dan untuk peserta didik yang memperoleh manfaat dari materi yang telah diberikan akan tetapi hanya $65 \%$ siswa yang berkesempatan untuk diskusi ataupun Tanya jawab antara pendidik dan peserta didik. Penugasan yang diberikan kemungkinan sangat erat ikatannya dengan beban kurikulum yang harus terpenuhi oleh pendidik, KEMENDIKBUD sebenarnya telah memberikan kebebasan kepada pendidik dari tuntutancapaian Kurikulum baik dalam kenaikan kelas ataupun untuk kelulusan Siswa. Adapun pengaruh dari pekerjaan orang tua dan ekonomi orangtua sudah pasti mendominasi dan menjadi factor pendukung dan cenderung menjadi kontribusi dalam pembelajaran daring. Dari hasil (Survei IPNU: 80,67\% Mahasiswa Tak Dapat Pembelajaran Daring... n.d.). Anak-anak yang belajar dengan menggunakan alat dalam jaringan rata-rata memiliki orang tua yang bekerja sebagai pegawai (39\%) dan pekerja lepas (26\%), serta latar belakang pendidikan minimal S1 (34\%) dan SMA (43\%). Sebaliknya, anak-anak yang sama sekali tidak diberikan tugas oleh sekolah mayoritas berasal dari mereka yang orang tuanya bekerja sebagai petani (47\%) dan berpendidikan hanya sekolah dasar (47\%) yang artinya, anak-anak dari kelompok kelas bawah rentan 
lebih banyak yang tidak belajar dibandingkan anak-anak yang berasal dari keluarga ekonomi kelas menengah. walaupun belum berjalan dengan sempurna, sebagian besar orang tua tetap dapat merasakan dampak positif dari kebijakan ini. Mereka menyatakan anak-anak menjalankan hidup lebih sehat dan mandiri (62\%), memiliki pengetahuan lebih banyak tentang kesehatan, termasuk COVID-19 (61\%), lebih sering membantu orang tua (56\%), dan memiliki kesempatan lebih banyak untuk mempelajari keterampilan hidup seperti mencuci, memasak, dan sejenisnya (53\%). Kesimpulan Pembelajaran jarak jauh memberikan kemudahan dan kesempatan dalam berbagai kondisi. Tidak pernah diprediksi sebelumnya keadaan dunia terkena covid-19. Untuk memotong mata rantai penyebaran, kita tetap dapat melakukan banyak hal positif di rumah.

\section{Perspektif Sosiologi Dalam Pendidikan Masa Covid-19}

"Menurut persepektif sosiologi, kegiatan belajar-mengajar melalui media sosial atau daring memang pas untuk kondisi seperti sekarang ini(nurdinah hanifah 2016,4) proses belajar mengajar tidak harus melakukan kontak fisik atau bertatap muka secara langsung,melainkam proses belajar mengajar bisa melalui sosial media/daring.oleh karena itu,instanti pendidikan mengalihkan pertemuan kelasnya dengan pertemuan daring ataupun tugas rumah guna meminalisir pertemuan satu sama lain di suatu ruangan yang sama dalam jarak yang dekat serta menghindari keramaian,sekarang sudah banyak sekolah-sekolah yang menggunakan proses belajarmengajar menggunakan media sosial/daring,tugas di berikan agar siswa bisa belajar walaupun dalam situasi seperti ini. Sedangkan di lingkungan perguruan tinggi ,mereka mengalihkan pertemuan kelas mereka dengan pertemuan daring dan tugas daring. Covid 19 sebagai gejala sosial kontak sosial, menggunakan kontak sekunder yaitu menggunakan perantara melalui teknologi. Dalam pertemuan kelas mereka, mereka harus dapat memanfaat kan media sosial dalam proses belajar mereka dengan baik."

Permasalahan sosial covid 19 ini menurut teori intraksi simbolis (Weber 2019, 10), yaitu teori labelling theory suatu kondisi sosial didalam masyarakat dikatakan bermasalah/adanya pelabelan. kondisi pandemi wabah covid-19 saat ini sebagai suatu masalah internasional. dan pada faktanya memang permasalahan virus corona membuat suatu kondisi masyarakat menjadi sangat menghawatirkan. 
masyarakat melabel permasalahan covid-19 ini adalah permasalahan yang sangat serius karena keadaan covid-19 berstatus darurat bencana non-alam oleh BNPB diperpanjang hingga tanggal 29 Mei 2020 (Kementerian Komunikasi dan Informatika n.d.). Permasalahan sosial yang diakibatkan covid-19 dirasakan oleh masyarakat terutama para siswa dan mahasiswa terkait belajar dirumah, para siswa mengeluh akan belajar dirumah dipenuhi dengan tugas rumah yang diberi oleh masing-masing guru terlalu banyak, sedangkan mahasiswa mengeluhkan bahwa pertemuan daring banyak terkendala oleh jaringan Web, teknologi yang kurang memadai, hingga sinyal. Selain itu pula kurang efektifnya belajar dirumah karena mereka belajar otodidak (sendiri), banyak orang tua yang tidak bisa mengajari materi yang ada dibuku, hanya bisa membimbing anaknya saja.

\section{Simpulan}

Adanya pandemi covid-19 juga memberikan hikmah yang lainnya. Pembelajaran yang dilakukan di rumah, dapat membuat orang tua lebih mudah dalam memonitoring atau mengawasi terhadap perkembangan belajar anak secara langsung. Orang tua lebih mudah dalam membimbing dan mengawasi belajar anak dirumah. Hal tersebut akan menimbulkan komunikasi yang lebih intensif dan akan menimbulkan hubungan kedekatan yang lebih erat antara anak dan orang tua. Orang tua dapat melakukan pembimbingan secara langsung kepada anak mengenai materi pembelajaran yang belum dimengerti oleh anak. Dimana sebenarnya orang tua adalah institusi pertama dalam pendidikan anak. Dalam kegiatan pembelajaran secara online yang diberikan oleh guru, maka orang tua dapat memantau sejauh mana kompetensi dan kemampuan anaknya. Kemudian ketidakjelasan dari materi yang diberikan oleh guru, membuat komunikasi antara orang tua dengan anak semakin terjalin dengan baik. Orang tua dapat membantu kesulitan materi yang dihadapi anak.

Namun tidak dapat dipungkiri pembelajaran daring juga membrikan dampak yang negatif, bisa dari belum memahami sistem daring, kurangnya sarana mulai dari kuota maupun jaringan. Sehingga banyak faktor terhambatnya pelaksanaan daring untuk berjalan dengan lancar.

Walaupun pendidikan di Indonesia ikut terdampak adanya pandemi covid-19 ini, namun dibalik semua itu terdapat hikmah dan pelajaran yang dapat diambil. Adanya kebijakan pemerintah untuk 
melakukan pembelajaran jarak jauh melalui online, maka dapat memberikan manfaat yaitu meningkatkan kesadaran untuk menguasai kemajuan teknologi saat ini dan mengatasi permasalahan proses pendidikan di Indonesia. 


\section{DAFTAR PUSTAKA}

"5 Fakta Tentang Program Belajar Dari Rumah Di TVRI Kumparan.Com." https://kumparan.com/kumparanmom/5-faktatentang-program-belajar-dari-rumah-di-tvri-1tESJEB80AV/full (June 11, 2020).

Amri Tanduklangi, Carlina Amri. 2019. Manajemen Sumber Daya Pembelajaran Bahasa Berbantuan Komputer: Computer. Yogyakarta.

Anderson, Terry. 2008. AU Press, Athabasca University The Theory and Practice of Online Learning. Canada: AU Press, Athabasca University.

Creswell, John W. 2013. Qualitative Inquiry and Research Design: Choosing Among Five Approaches. United Kingdom.

"Evaluasi Dan Optimalisasi Pembelajaran Daring." https://news.detik.com/kolom/d-4960905/evaluasi-danoptimalisasi-pembelajaran-daring (June 11, 2020).

"Imbas Pandemi Virus Corona Bagi Dunia Pendidikan Indonesia Dan Global - Kumparan.Com." https://kumparan.com/kumparansains/imbas-pandemi-viruscorona-bagi-dunia-pendidikan-indonesia-dan-global1t5YVXRYAbo (June 11, 2020).

"Kementerian Komunikasi Dan Informatika." https://kominfo.go.id/content/detail/25140/bnpb-perpanjangstatus-darurat-covid-19-hingga-29-mei-2020/0/berita (June 11, 2020).

"Kementerian Pendidikan Dan Kebudayaan » Republik Indonesia." https://www.kemdikbud.go.id/main/blog/2020/03/mendikbudterbitkan-se-tentang-pelaksanaan-pendidikan-dalam-masadarurat-covid19 (June 11, 2020).

"Kepala Sekolah, Sekarang Bisa Pakai Dana BOS Untuk Pulsa Dan KuotaInternet." 
https://www.kompas.com/edu/read/2020/04/15/170956671/kepal a-sekolah-sekarang-bisa-pakai-dana-bos-untuk-pulsa-dan-kuotainternet (June 11, 2020).

"Kisah Dari Wuhan, Awal Pandemi Virus Corona Yang Tidak Akan Terlupakan...’https://www.kompas.com/tren/read/2020/04/14/07 0100165/kisah-dari-wuhan-awal-pandemi-virus-corona-yangtidak-akan-terlupakan (June 11, 2020).

Kurniasih, Imas, and Berlin Sani. 2014. Implementasi Kurikulum 2013 : Konsep \& Penerapan.

Moleong, Lexy J. 2018. Metodologi Penelitian Kualitatif. Bandung: PT Remaja Rosdakarya.

Nurdinah Hanifah. 2016. Sosiologi Pendidikan. Sumedang: UPI Sumedang Press.

"Pengumuman Mendadak Jokowi Yang Kejutkan Pasien Positif Corona..."'https://nasional.kompas.com/read/2020/03/04/080513 61/pengumuman-mendadak-jokowi-yang-kejutkan-pasienpositif-corona (June 11, 2020).

Punaji Setyosari. 2007. "Pembelajaran Sistem Online: Tantangan Dan Rangsangan."https://journal.uny.ac.id/index.php/mip/article/vie w/5992 (June 11, 2020).

Rama, Bahaking. 2014. Teori Pelaksanaan Pembelajaran Dalam Pendidikan Islam.

"Survei IPNU: 80,67\% Mahasiswa Tak Dapat Pembelajaran Daring....'https://nasional.sindonews.com/read/15023/144/survei -ipnu-8067-mahasiswa-tak-dapat-pembelajaran-daring-darikampus-1588421157 (June 11, 2020).

Weber, - Max. 2019. Sosiologi Agama. Boston: IRCISOD.

Wildavsky, Aaron. 2017. Budgeting and Governing. USA: Rautledge. 